\title{
Japanese Small Type Coastal Whaling
}

\author{
Sue Fisher* \\ Animal Welfare Institute, Washington, DC, USA
}

2016 marks the 70th anniversary of the International Convention for the Regulation of Whaling (ICRW) as well as the 30th anniversary of the International Whaling Commission's (IWC) moratorium on commercial whaling. It also marks three decades of effort by Japan to overturn this ban. Its strategy to circumvent the moratorium by issuing permits to kill protected whales for scientific research is famous - even the subject of a 2014 lawsuit at the International Court of Justice. Less well known is Japan's strategy to overturn the ban by persuading the Commission to authorize a category of commercial whaling known as Small Type Coastal Whaling (STCW) that is conducted on minke and other small whales in Japanese waters but has never been regulated, or even formally recognized, by the IWC. For three decades Japan has sought STCW catch limits for four communities which it claims are still suffering distress as a result of the moratorium. While the Commission has rejected each proposal, mainly citing concerns that the commercial nature and purpose of STCW violates the moratorium, Japan has persisted, exhibiting great flexibility in its approach. Its tactics changed significantly in 2014; it no longer denied (or defended)

OPEN ACCESS

Edited by:

Mark Peter Simmonds, University of Bristol, UK

Reviewed by:

Peter Corkeron National Oceanic and Atmospheric

Administration, USA Russell Christopher Leaper, University of Aberdeen, UK

*Correspondence. Sue Fisher sue.fisher@balaena.org

Specialty section: This article was submitted to Marine Affairs and Policy,

a section of the journal Frontiers in Marine Science

Received: 18 March 2016 Accepted: 23 June 2016 Published: 18 July 2016

Citation:

Fisher S (2016) Japanese Small Type Coastal Whaling.

Front. Mar. Sci. 3:121 doi: 10.3389/fmars.2016.00121 the commerciality of the hunt, but argued that it is irrelevant since it sought only a small exemption to the moratorium which would remain intact for all other populations. This is a perspective on Japan's evolving STCW strategy and the risk that lifting, or modifying, the moratorium would pose to the conservation of whales.

Keywords: Japan, International Whaling Commission, moratorium

\section{BACKGROUND}

The devastation wreaked on whale populations by centuries of unregulated, and later poorly regulated, commercial whaling is renowned: 2.9 million whales were killed in the 1900s (Rocha et al., 2014). Targeted on an industrial scale for their oil and, more recently, for their meat, many of the 13 species of "great" whales (baleen whales plus the sperm whale) suffered catastrophic declines. Some populations were lost entirely, including the North Atlantic gray whale (Reilly et al., 2008). Others, including the North Atlantic right whale, survive only in the low hundreds today, even after decades of protection (Reilly et al., 2008).

The International Convention for the Regulation of Whaling (ICRW) (IWC, 1946a) was negotiated at the end of World War II by the leading whaling nations (with the exception of Japan which joined in 1951) in an attempt to bring order to the extreme competition that had long characterized commercial whaling. The ICRW established the International Whaling Commission (IWC or Commission) whose (now 88) contracting governments implement the ICRW's objective to "provide for the proper conservation of whale stocks and thus make possible the orderly development of the whaling industry." This is achieved through the adoption of legally binding regulations, including catch limits (also known as quotas), into a schedule (IWC, 2015a) that "forms an integral part" of the convention (IWC, 1946b). 
Regrettably, for the next four decades the IWC continued to set unsustainable catch limits for many populations and, because the ICRW lacked any enforcement mechanisms, remained unable to prevent or punish extensive illegal hunting and mis- or non-reporting of catches. Nations also evaded regulations by conducting whaling for scientific research and by lodging objections that exempted them from the Commission's decisions. Both practices are allowed by the convention: Article VIII permits contracting governments to issue "special permits" authorizing whaling "for purposes of scientific research," while Article V allows objections.

By the 1960s more than 70,000 whales were killed annually (Rocha et al., 2014). The IWC began to protect the most vulnerable species in 1966 but did not adopt a total ban on commercial whaling until 1982. Specifically, it agreed a new schedule paragraph 10 (e) which set catch limits "for the killing for commercial purposes of whales from all stocks" to zero after a 4 year phase-in period (IWC, 1982). Around the same time its Scientific Committee began developing a more precautionary quota-setting model for future commercial whaling that would set all catch limits to zero by default until scientific evidence showed that sustainable catch limits could be set for a specific population. The Commission accepted the specifications of this Revised Management Procedure (RMP) in 1994 (IWC, 1994a) but will not adopt it into the schedule until it has established a Monitoring, Control and Surveillance (MCS) regime, as part of a Revised Management Scheme (RMS) (IWC, 1994a).

\section{JAPAN'S RESPONSE TO THE MORATORIUM}

Although all other remaining commercial whaling nations (Brazil, Spain, Korea, Iceland and the Philippines) ceased whaling in accordance with the moratorium, Japan, Norway, Peru and the Soviet Union lodged objections (IWC, 1982). Threatened with exclusion from valuable fishing grounds and other sanctions, Japan-then the leading whaling nation-was persuaded by the United States to withdraw its objection in 1987 (ICJ, 2011) although the other major hunters, Norway and the Soviet Union, retained their objections (Peru removed its objection in 1983). However, Japan immediately announced its intention to use Article VIII to hunt hundreds of whales annually on their Antarctic feeding grounds in a "feasibility study" that in 1989 became the 12 year (but subsequently extended) Japanese Whale Research Program under Special Permit in the Antarctic (JARPA, later JARPA-II). In 1994, it launched the Japanese Whale Research Program under Special Permit in the North Pacific (JARPN, later JARPN-II) which uses the same factory fleet. Japan and others had issued special permits before but never on such a scale or so blatantly for commercial purposes. Article VIII states that whales taken shall be processed "so far as possible" and the "proceeds" dealt with in accordance with directions issued by the government concerned; Japan interprets this as a mandate to sell the whale products through existing commercial markets.

Japan's use of Article VIII to keep its pelagic fleet operative and producing thousands of tons of whale meat a year despite the moratorium is widely criticized: It is the topic of countless hours of debate at IWC meetings, 25 IWC resolutions calling on Japan to reconsider its programmes, multiple diplomatic complaints and the threat of trade sanctions ${ }^{1}$. Moreover, the International Court of Justice (ICJ) ruled in 2014 that JARPA-II "is not for the purposes of science" and should stop (ICJ, 2014a). (Japan modified the programme and resumed Antarctic whaling in late 2015). In contrast, its efforts over the last 30 years to persuade the IWC to allow its small-scale, near-shore whaling operation known as "Small Type Coastal Whaling (STCW)" to resume legal commercial hunting of minke whales in its coastal waters are far less well-known.

Yet, because the ultimate goal of Japan's STCW strategy is to overturn, rather than circumvent, the moratorium, it may ultimately be more damaging. Lifting the moratorium, or modifying it for specific stocks, would make commercial whaling legal for the first time in three decades, enabling Norway, which currently hunts minke whales under objection, and Iceland, which uses a reservation to the moratorium to hunt fin and minke whales, to finally avoid reproach for "abusing loopholes" (WDC, $2015^{2}$ ). It would also open opportunities for other nations which have a market for whale meat that is not currently satisfied. For example, the Republic of Korea has asserted that if Japan is given an STCW quota, it would issue a similar demand (IWC, 1994b).

Furthermore, the IWC's prohibitions on commercial whaling up to and including the moratorium were the impetus for CITES, the Convention on International Trade in Endangered Species of Wild Fauna and Flora, to place all great whales ${ }^{3}$ on its Appendix I (CITES, 2016) which prohibits international trade for primarily commercial purposes. Although the remaining whaling nations already trade whale products with each other under CITES reservations, they seek greater market access, including for new products, such as health supplements, that they are developing from whales (WDCS, 2010) and Norway and Japan have repeatedly sought to "downlist" whales to Appendix II. While CITES Parties have so far rejected each of these attempts, instead recommending in 2000 that "Parties agree not to issue any import or export permit... for any specimen of a species or stock protected from commercial whaling by the International Convention for the Regulation of Whaling" (CITES, 2000), given that CITES follows the IWC's lead in managing whales, lifting the moratorium, even fractionally, is likely to revive demands to allow international commercial trade to resume.

\section{JAPAN'S STCW STRATEGY}

STCW is a Japanese category of whaling, conducted in a handful of towns, that is characterized by the species targeted (mainly Baird's beaked whales, short-finned pilot whales and Risso's

\footnotetext{
${ }^{1}$ United States Presidents Reagan, Clinton and G.W. Bush have all contemplated trade sanctions against Japan under the Pelly Amendment to the Fishermen's Protective Act 22 U.S.C. $\$ 1978$, as amended Pub. L. No. 95-376, 92 Stat. 714 (Sept. $18,1978)$

${ }^{2}$ WDC (2015). Available online at: http://us.whales.org/wdc-in-action/whaling

${ }^{3}$ With the exception of the West Greenland minke whale which remains on Appendix II.
} 
TABLE 1 | STCW requests, catches of small cetaceans by STCW operations and minke whale catches in JARPN/JARPN II since the moratorium came into effect.

\begin{tabular}{|c|c|c|c|c|c|}
\hline \multirow[t]{2}{*}{ Year } & \multirow[t]{2}{*}{$\begin{array}{l}\text { Annual STCW } \\
\text { quota sought }\end{array}$} & \multicolumn{3}{|c|}{$\begin{array}{l}\text { Catches of small } \\
\text { cetaceans }\end{array}$} & \multirow[t]{2}{*}{$\begin{array}{c}\text { JARPN/JARPN II } \\
\text { minke catches (coastal) }\end{array}$} \\
\hline & & Baird's beaked whale & Pilot whales & Risso's dolphins & \\
\hline 1986 & 210 minke whalesr & 40 & 62 & & \\
\hline 1987 & No proposal & 40 & & & \\
\hline 1988 & 210 minke whales & No data found & No data found & No data found & \\
\hline 1989 & 320 minke whales & 54 & 58 & & \\
\hline 1990 & 50 minke whales & 54 & 18 & 11 & \\
\hline 1991 & 50 minke whales & 54 & 59 & 92 & \\
\hline 1992 & 50 minke whales & 54 & 81 & 30 & \\
\hline 1993 & 50 minke whales & 54 & 91 & & \\
\hline 1994 & 50 minke whales & 54 & 55 & 20 & $21^{*}$ \\
\hline 1995 & 50 minke whales & No data found & No data found & No data found & $100^{*}$ \\
\hline 1996 & 50 minke whales & No data found & No data found & No data found & $77^{\star}$ \\
\hline 1997 & 50 minke whales & 54 & 77 & 20 & $100^{*}$ \\
\hline 1998 & 50 minke whales & 54 & 84 & 20 & $100^{*}$ \\
\hline 1999 & 50 minke whales & 62 & 104 & 12 & $100^{*}$ \\
\hline 2000 & 50 minke whales & 62 & 106 & 20 & $40^{\star}$ \\
\hline 2001 & 50 minke whales & 62 & 87 & 17 & $100^{*}$ \\
\hline 2002 & No proposal & 62 & 83 & 12 & 50 \\
\hline 2003 & 150 minke whales & 62 & 69 & 19 & 50 \\
\hline 2004 & 100 minke whales & 62 & 42 & 7 & 60 \\
\hline 2005 & 150 minke whales 150 Bryde's whales withdrawn before vote & 66 & 47 & 8 & 121 \\
\hline 2006 & 150 minke whales 150 Bryde's whales withdrawn before vote & 63 & 17 & 7 & 97 \\
\hline 2007 & No number specified & 67 & 16 & 20 & 108 \\
\hline 2008 & No number specified & 64 & 20 & & 112 \\
\hline 2009 & No proposal & 67 & 22 & & 122 \\
\hline 2010 & No proposal & No data found & No data found & No data found & 105 \\
\hline 2011 & No proposal & 61 & & & 77 \\
\hline 2012 & No proposal & 71 & 16 & & 110 \\
\hline 2013 & No proposal & 62 & 10 & & 92 \\
\hline 2014 & $<17$ minkes/year & Data not available & & & 81 \\
\hline
\end{tabular}

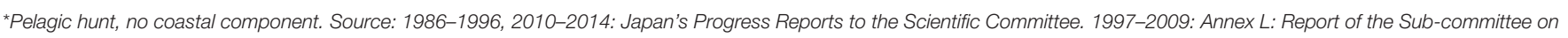
small cetaceans. Appendix 2. j. cetacean res. manage. 13 (suppl.), 2012.

dolphins in addition to minke whales; see Table $\mathbf{1}$ for catches since the moratorium). Although these are smaller species, the "small" in STCW actually derives from the size (maximum 48 tons) and short range of the vessels used (Kalland and Moeran, 1997). STCW is not a category of whaling regulated, or even recognized, by the IWC which for 70 years has governed only commercial and special permit whaling as well as hunting by indigenous people for nutritional and cultural subsistence, known as Aboriginal Subsistence Whaling (ASW). Moreover, the IWC does not regulate the hunting of species other than the great whales (which includes the minke whale) due to disagreement over its legal competence to manage "small cetaceans"-small toothed whales, dolphins and porpoises including those targeted in STCW.

The 2014 ICJ decision confirmed there can be no categories of whaling falling outside Article VIII or the schedule provision regulating ASW that are exempt from the prohibition on commercial whaling in $10(\mathrm{e})$. Although the court did not directly consider STCW, it is clear from its decision that by authorizing STCW on a species protected by 10 (e) the IWC would not only exceed the scope of the ICRW, it would "undermine its object and purpose" (ICJ, 2014b).

Japan first sought STCW catch limits for minke whales in 1986, the year the moratorium came into effect; it sought an annual quota of 210 to meet the needs of three coastal towns, Ayukawa, Kushiro, and Abashiri, that had, until then, hunted minke as well as Baird's beaked and pilot whales and sold surplus meat throughout their respective regions (IWC, 1986). At the time the IWC was considering how to regulate ASW in light of the moratorium and Japan asserted that denial of its request would have the same damaging impact on STCW communities as it would on indigenous subsistence whalers. Conflating ASW 
and STCW by claiming similarities in their nature, size and history, Japan stated that "the tradition of whaling in the [STCW] community is a complex and deep-rooted socio-economic element based on the long history of religion, custom and social behaviour which have survived through the centuries to the present day, on which the solidarity of the entire community has been built" (IWC, 1986).

While STCW does have a long tradition in parts of Japan and is different in nature and scale from modern commercial whaling, it is also quite distinct from whaling for the purpose of nutritional and cultural subsistence that is conducted by indigenous people in remote, and typically harsh, environments for their local consumption (IWC, 2015b). Indeed, the framers of the ICRW explicitly recognized the needs of such indigenous people in both the final act of the convention and its first schedule (Tillman, 2008), establishing a legal mandate for the regulation of ASW that the IWC has exercised ever since. The IWC was not persuaded that Japan's STCW hunt should be treated like ASW and exempted from the moratorium.

Then, and now, the main objection to STCW is that it is an inherently commercial enterprise and therefore prohibited by paragraph 10(e). Indeed, Japan's first accounts of its longstanding STCW operations described clear for-profit elements, including sales by 10 wholesalers and almost 300 retailers, and regional sales of surplus (IWC, 1986). Displaying a flexibility that has come to characterize its STCW strategy, in subsequent proposals Japan denied or de-emphasized the commercial nature of the whaling operation; for example, it claimed in its third proposal (IWC, 1988) that a significant proportion of whale meat was distributed through non-commercial channels such as gifting. It also began to place greater emphasis on the social and cultural importance of STCW, interchangeably calling it "community based whaling." The assertion that the moratorium caused "socio-cultural, dietary, religious, occupational and psychological" distress to its STCW communities, and that the IWC has a responsibility to mitigate those harms, has remained a consistent element in Japan's requests and the Commission has recognized the needs of the communities and committed to "work expeditiously to alleviate the distress" (for example, IWC, 1993). But it did so initially in response to an offer of "formal assurances" by Japan that meat taken in STCW "shall not become the object of any commercial distribution". With Japan's ongoing STCW operations continuing to be (and acknowledged by Japan to be) commercial in nature and purpose, the Commission does not have the legal optionas the ICJ confirmed-to grant "relief" that would violate the moratorium.

Apparently undeterred by the repeated rejections of its proposals -17 have been defeated and the rest were withdrawn or never put to a vote-Japan has persisted. For each concern raised by IWC Commissioners, a subsequent proposal has typically offered a rejoinder or taken a new approach. For example, in the mid-1990s, Japan tried to remove all commercial elements from several of the action plans that accompanied its requests; replacing "sales" with "levies" and "reimbursements," limiting processing to portions of less than $1 \mathrm{~kg}$, and transferring legal ownership of hunted whales to management councils which would distribute meat to schools, nursing homes and to community festivals. It even proposed fixing the price of whale meat sold in guest houses to avoid profit-making (IWC, 1995). When this failed to convince the Commission, it reversed approach in 2003-instead embracing the commercial aspects of the hunt and seeking a higher catch limit to "vitalise the local economy by promoting local processing industries and stimulating tourism" (IWC, 2003).

Japan has taken a similarly adaptable approach to addressing MCS issues. For example, it responded to concerns about how products from minke whales taken for non-commercial purposes would be prevented from entering the well-developed and high value market for Baird's beaked whales that used the same vessels, crews, ports and processing facilities by incorporating elements of the RMS then being negotiated by the Commission such as global positioning systems on boats, local inspectors at ports, a DNA database of whale meat and penalties for unauthorized selling of whale products (IWC, 1995). The flexibility of its proposals has even extended to the communities seeking an STCW quota; while Japan initially sought catch limits to meet the needs of Kushiro, Abashiri and Ayukawa, it subsequently dropped Kushiro and added Taiji and Wada (IWC, 1990), only to reinstate Kushiro (where a new whaling station was to be built) in 2003 (IWC, 2003) after Japan began sub-contracting a coastal component of JARPN-II to STCW vessels.

However, the most variable element in STCW proposals has been the number, and even the species, of whales claimed to be needed by STCW communities in addition to meat from their ongoing - and relatively stable - small cetaceans takes. In the early years, Japan sought 210 (IWC, 1986) or 320 (IWC, 1989) minke whales a year to satisfy need, while from 1990 (when it offered to reduce its Baird's beaked whale quota) to 2003 it requested a more symbolic "emergency relief quota" of 50 whales a year (IWC, 1990). Its proposal expanded to 150 minke whales in 2003 (IWC, 2003), dropped to 100 in 2004 then, for 2 years, included an additional 150 Bryde's whales (IWC, 2005, 2006) although this is not a species traditionally hunted in STCW. Japan did not identify a number of whales in its 2007 and 2008 proposals, but sought advice directly from Scientific Committee on an appropriate catch limit (IWC, 2007). After pausing its requests between 2009 and 2012 when the IWC attempted to avoid controversial issues while it focused its discussions on its future, Japan most recently sought 17 minke whales in 2014 (IWC, 2014a).

Governments routinely express concern about the sustainability of the proposed hunt. Minke whales in the North Pacific comprise at least two and probably more genetically distinct stocks including a depleted population known as J-stock. J-stock whales mix at certain times of the year with the more populous $\mathrm{O}$-stock and are vulnerable to both high levels of by-catch by Japan and South and North Korea and JARPN-II (Baker et al., 2000). Japan has responded in various ways to concerns about the potential impact of STCW on these stocks but most recently in 2014, it claimed the impact on the stocks would be negligible because it calculated the proposed catch limit "in light of the RMP Implementation Review completed in 2013" (IWC, 2014c). In fact the Scientific 
Committee had determined that the experimental variant of the RMP used by Japan to generate a catch limit of 17 minke whales would be acceptable only with additional research and, overall, was one of the worst performing of 10 variants reviewed in 2013 (IWC, 2014b). In addition, Japan's 2014 proposal did not take into account the Commission's longstanding agreement (IWC, 2000) that whales killed in by-catch should be deducted from catch limits calculated by the RMP. Nor did it commit to reduce catches in proportion to the number of minke whales (up to 120 a year have been taken since 2002) in the coastal component of JARPN II conducted by STCW vessels and sold locally (Suisan Keizai News, $2005^{4}$ ). In contrast Japan offered to offset these takes in 2007 (IWC, 2007).

\section{4-A NEW APPROACH}

Japan's approach changed significantly in 2014-the first time the Commission had met on a new biennial cycle and following the ICJ decision. Claiming that it had no wish to change or delete paragraph 10(e) which, it insisted, would remain in operation if its proposal was adopted, Japan proposed an exemption to the moratorium via a new paragraph that would apply "notwithstanding" 10(e)'s provisions (IWC, 2014d). Paragraph 10(f) would establish a 5 years block of catch limits for the single stock of minke whales in the western North Pacific on which it had tested a variant of the RMP. Although the proposal was rejected, Japan's Commissioner subsequently sought governments' input to a "consultative questionnaire" to "identify remaining arguments and issues that need further

${ }^{4}$ Minke Whale Meat Arrives at Sendai Market for the First Time From Research Whaling off Sanriku. April 15th, 2005. Suisan Keizai News. Text on file with author.

\section{REFERENCES}

Anon (2016). Confidential Personal Communication with IWC Commissioners, Anon.

Baker, C. S., Lento, G. L., Cipriano, F., and Palumbi, S. R. (2000). Predicted decline of protected whales based on molecular genetic monitoring of Japanese and Korean markets. Proc. R. Soc. Lond. B 267, 1191-1199. doi: $10.1098 /$ rspb. 2000.1128

CITES (2000). "Conservation of cetaceans, trade in cetacean specimens and the relationship with the International Whaling Commission," in Resolution Conf. 11.4 (Rev. CoP12). Available online at: https://cites.org/eng/res/11/ 11-04.php

CITES (2016). Appendix I. Available online at: https://cites.org/eng/app/ appendices.php

ICJ (2011). Memorial of Australia, vol. I, P70-P76. Available online at: http://www. icj-cij.org/docket $/$ index.php?p1 $=3 \& \mathrm{p} 2=3 \& \mathrm{k}=64 \&$ case $=148 \& \operatorname{code}=a j \& \mathrm{p} 3=1$

ICJ (2014a). Whaling in the Antarctic (Austl. v. Japan), 2014 I.C.J. 148. Available online at: http://www.icj-cij.org/docket/index.php?p1=3\&p2=3\&k=64\&case= $148 \&$ code $=$ aj\&p $3=3.72$

ICJ (2014b). Whaling in the Antarctic (Austl. v. Japan), 2014 I.C.J. 148. Available online at: http://www.icj-cij.org/docket/index.php?p1=3\&p2=3\&k=64\&case= $148 \& \operatorname{code}=$ aj\&p3 $=3.66$

IWC (1946a). International Convention for the Regulation of Whaling. Stat. 1716, 161 U.N.T.S. 72, IWC.

IWC (1946b). International Convention for the Regulation of Whaling. Art. I. 10, 62 Stat. 1716, 161 U.N.T.S. 72 , IWC. discussion" (Morishta, 2015 ${ }^{5}$ ) and Japan has approached opposing governments during the intersessional period to discuss their concerns (Anon, 2016). These unprecedented attempts at outreach signal the importance of its STCW strategy to Japan, particularly in light of its acknowledgment that it must revise JARPN-II as well as its Antarctic programme "in light of the ICJ ruling" (Jiji News, 2016 ${ }^{6}$ ) which likely means a reduction in special permit catches-and therefore meat-from the North Pacific.

The timing of this apparent increase in effort around STCW is particularly significant as Japan will assume the chairmanship of the Commission at the end of the 2016 meeting and its Commissioner will oversee the IWC's negotiation of new ASW catch limits in 2018. STCW may never rival special permit whaling for attention but, given the risks of lifting or modifying the moratorium, Commissioners should pay close attention to the STCW proposal that Japan is expected to bring to the next meeting.

\section{AUTHOR CONTRIBUTIONS}

The author confirms being the sole contributor of this work and approved it for publication.

\section{FUNDING}

This research was supported by Animal Welfare Institute.

${ }^{5}$ Letter Joji Morishta, 21 January 2015. Downloaded at https://iwc.int/stcw on 3 March 2016

${ }^{6}$ Scientific whaling in the northwest Pacific to be completely revised, new program to be created this fall. Jiji News, 22 April, 2016. Available online at: http://www.jiji. $\mathrm{com} / \mathrm{jc} / \mathrm{article} \mathrm{k}=2016042200349 \& \mathrm{~g}=\mathrm{eco}$
IWC (1982). International Convention for the Regulation of Whaling, Schedule Art. III, 10(e), 62 Stat. 1716, 161 U.N.T.S. 72, IWC.

IWC (1986). Small Type Whaling in Japan's Coastal Seas. Submitted by the Government of Japan. TC38/AS2. 26-27, IWC.

IWC (1988). Chairman's Report of the 39th Annual Meeting. Report of the International Whaling Commission 38. 22.

IWC (1989). Chairman's Report of the 41st Annual Meeting. Report of the International Whaling Commission 40, 1990. 27.

IWC (1990). Chairman's Report of the 42nd annual meeting. Report of the International Whaling Commission. 41, 1991. 33.

IWC (1993). "Resolution on Japanese Community-based Minke Whaling," in Chairman's Report of the 46th Annual Meeting. Report of the International Whaling Commission, 44, 1994. 31.

IWC (1994a). "IWC Resolution 1994-5. Resolution on the Revised Management Scheme," in 46th Annual Meeting, 1994. Report of the International Whaling Commission, 45 .

IWC (1994b). Chairman's Report of the 46th Annual Meeting. Report of the International Whaling Commission. 45. 1995. 18.

IWC (1995). Action Plan for Japanese Community-Based Whaling (CBW) (Revised). Government of Japan, IWC/47/46.

IWC (2000). Chairman's Report of the Fifty-Second Annual Meeting. Annual Report of the International Whaling Commission, 2000. 33.

IWC (2003). Chair's Report of the 55th Annual Meeting. Report of the International Whaling Commission 2003. 28.

IWC (2005). Chair's Report of the 57th Annual Meeting. Report of the International Whaling Commission 2005. 35. 
IWC (2006). Chair's Report of the 58th Annual Meeting. Report of the International Whaling Commission 2006. 28.

IWC (2007). Chair's Report of the 59th Annual Meeting. Report of the International Whaling Commission 2007. 33-37.

IWC (2014a). Chair's Report of the 65th Meeting. Report of the International Whaling Commission 2014, 12-13.

IWC (2014b). Journal of Cetacean Research and Management. 15 (suppl.), 2014. Report of the Scientific Committee, IWC, 11-15.

IWC (2014c). Japan's Proposal and its Background for Schedule Amendment to Permit the Catching of Minke Whales from the Okhotsk Sea-West Pacific Stock by Small-Type Coastal Whaling Vessels. IWC/65/09

IWC (2014d). Additional Information to IWC/65/09 (Japan's Proposal and its Background for Schedule Amendment to Permit the Catching of Minke Whales from the Okhotsk Sea-West Pacific Stock by Small-Type Coastal Whaling Vessels), IWC/65/21.

IWC (2015a). Schedule As amended by the Commission at the 65th Meeting Portorož, Slovenia. Available online at: https://iwc.int/convention

IWC (2015b). Schedule As amended by the Commission at the 65th Meeting Portorož, Slovenia. Paragraph 13 (b) (1), (2), (3), (4). Available online at: https:// iwc.int/convention

Kalland, A., and Moeran, B. (1997). Japanese Whaling: End of an Era? London: Curzon Press.

Morishta, J. (2015). Letter to Simon Brockington, Secretary of the IWC. Available online at: https://iwc.int/stcw
Reilly, S. B., Bannister, J. L., Best, P. B., Brown, M., Brownell Jr., R. L., Butterworth, D. S., et al. (2008). Eschrichtius robustus. The IUCN Red List of Threatened Species 2008: e.T8097A12885255. Available online at: http://dx.doi.org/10. 2305/IUCN.UK.2008.RLTS.T8097A12885255.en. Downloaded on 16 March, 2016

Rocha, R. C., Clapham, P. J., and Ivashchenko, Y. V. (2014). Emptying the oceans: a summary of industrial whaling catches in the 20th century. Marine Fish. Rev. $76,37-48$.

Tillman, M. F. (2008). The international management of aboriginal whaling. Rev. Fish. Sci. 16, 437-444. doi: 10.1080/106412608020 13932

WDCS (2010). Reinventing the Whale. Available online at: http://us.whales.org/ reinventing-whale

Conflict of Interest Statement: The author declares that the research was conducted in the absence of any commercial or financial relationships that could be construed as a potential conflict of interest.

Copyright (c) 2016 Fisher. This is an open-access article distributed under the terms of the Creative Commons Attribution License (CC BY). The use, distribution or reproduction in other forums is permitted, provided the original author(s) or licensor are credited and that the original publication in this journal is cited, in accordance with accepted academic practice. No use, distribution or reproduction is permitted which does not comply with these terms. 